\title{
NILAI-NILAI DALAM SASTRA ANAK SEBAGAI SARANA PEMBENTUKAN KARAKTER
}

\author{
Abdul Rosid \\ Pendidikan Bahasa dan Sastra Indonesia, Universitas Trunojoyo Madura \\ Email: Abdul.rosid@trunojoyo.ac.id
}

\begin{abstract}
Abstrak
Tradisi mendongeng sebelum tidur padamasa lalu sangat sering dilakukan oleh orang tua sebagai kegia tan pengantar tidur untuk anaknya. Hal ini dila kukan a gar anak memperoleh pembelajaran tentang nila i yang terkandung dalam cerita tersebut. Seiring berja lannya waktu kegiatan tersebut mulai ditinggalkan. karya sa stra yang dikhususkan untuk kanak-kanak, dike nal sebagai sa stra a nak. Berdasarkan kenyataan ini da pat dipahami, bahwa terdapat fenomena dalam dunia penulisan kreatif bahwa ada saatnya di mana penulis kreatif (sastrawan, penyair, dramawan) telah menetapkan terlebih dahulu secara khusus sia pa pembaca yang dituju dari ka rya yang a kan diciptakannya. Pendekatan dalam penelitian ini a dalah pendekatan kualitatif deskriptif. Pendekatan kua litatif menyajikan data-data dalam bentuk deskriptif yaitu berupa kata-kata, gambar, bagan, dan bukan angka-angka. Berdasarkan hasil pem bahasan dalam artikel ini da pat dism pulkan bah wa dala m buku kumpulan cerita anak cerdas mengandung nilai- nilai dia n tara nya nilai sem angat, menjaga kebersihan, menjaga kelestarian lingkungan, menyayangi orang tua, dan gotong ro y on $\mathrm{g}$. Nila i-nila itersebut sa ngat bermanfaat untuk membentuk karakter anak dan dapat dijadikan bahan pelajaran bagi anak-anak dalam kehidupan sehari- hari.
\end{abstract}

Kata Kunci: sastra anak; pendidikan karakter; mendongeng.

\section{PENDAHULUAN}

Dunia anak merupakan dunia yang paling menyenangkan dalam fase kehidupan manusia, dunia hayal, dunia bermain yang penuh warna dan tak terlupakan. Banyak sekali jenis permainan anak yang dapat di eksplorasi untuk dimainkan oleh mereka. Selain itu jenis bacaan anak juga sangat beragam, ada dongeng, fabel, dan bacaan yang bergenre sastra lainnya.

Tradisi mendongeng sebelum tidur pada masa lalu sangat sering dilakukan oleh orang tua sebagai kegiatan pengantar tidur untuk anaknya. Hal ini dilakukan agar anak memperoleh pembelajaran tentang nilai yang terkandung dalam cerita tersebut. Seiring berjalannya waktu kegiatan tersebut mulai ditinggalkan.

Sastra lahir dari proses kegelisahan sastrawan atas kondisi masyarakat dan terjadinya ketegangan atas kebudayaannya. Sastra sering juga di sebut sebagai potret sosial. Ia menggambarkan kondisi masyarakat pada masa tertentu. Sastra juga di anggap merupakan manivestasi semangat pada zamannya. Dari hal tersebut sastra dapat memberikan pemahaman tentang situasi sosial, kepercayaan, ideology, dan harapan- harapan seseorang yang sebenarnya. Salah satu bentuk karya sastra adalah prosa. Prosa adalah bentuk karangan sastra dengan Bahasa biasa, bukan Bahasa puisi, terdiri atas kalimat- kalimat yang jelas runtutan pemikirannya, biasanya ditulis dalam alineaalinea. Ragam prosa antara lain adalah prosa fiksi.

Berdasarkan kriteria siapa pembacanya, isi sastra dapat dipilah dalam berbagai penjenisan. Jika sebuah novel ditulis dan diterbitkan khusus untuk pembaca dewasa, akan muncul istilah novel atau fiksi untuk pembaca dewasa. Jiak pembaca sasarannya kelompok remaja, karya sastra karya sastra yang dihasilkan disebut sastra remaja. Oleh sebab itu, karya sastra yang dikhususkan untuk kanak- kanak, dikenal sebagai sastra anak. Berdasarkan kenyataan ini dapat dipahami, bahwa terdapat fenomena dalam dunia penulisan kreatif bahwa ada saatnya di mana penulis kreatif (sastrawan, penyair, dramawan) telah menetapkan terlebih dahulu secara khusus siapa pembaca yang dituju dari karya yang akan diciptakannya.

Di dalam pengertian umum, kata "anak" dalam hal ini mungkin lebih tepat disebut dengan istilah "kanak- kanak" dapat ditujukan kepada manusia yang berusia antara 6 sampai 12 tahun. Jika ditinjau dari jenjang pendidikannya, anak dengan usia tersebut adalah kanak- kanak pada jenjang pendidikan sekolah dasar. Sastra anak, secara dikotomi dapat dikatakan sebagai karya sastra yang "layak" dibaca, didengar, atau di 


\section{Volume 6 No. 1 METALINGUA \\ April 2021 Jurnal Pendidikan Bahasa dan Sastra Indonesia}

konsumsi oleh kanak-kanak. Kata "layak" memberikan gambaran bahwa ada persyaratan khusus tentang boleh tidaknya, baik tidaknya, atau sesuai tidaknya, sastra tersebut dibaca atau diperuntukkan bagi kanak- kanak. Kata "layak" juga mengisyaratkan isi sastra anak merupakan bagian penting.

Sebagaiman halnya dalam sastra dewasa, sastra anak juga mengenal apa yang disebut genre, maka pembicaraan genre sastra anak juga perlu dilakukan. Pembicaraan genre sastra anak dapat saja analog dengan pembedaan genre dalam sastra dewasa, yaitu dalam tiga besar genre puisi, fiksi, dan drama dengan masing- masing memiliki subgenre. Dengan demikian, pembicaraan tentang genre menjadi lebih sderhana. Namun genre sastra anak faktanya tidak sesederhana itu, maka pembedaan genre ke dalam tiga macam tersebut tidak dilakukan.

Berikut dijelaskan genre sastra anak menurut Lukens (Nurgiantoro,2019: 17) yang tampak berbeda dengan genre sastra dewasa dan sekaligus juga berdasarkan tiga pemikiran perlunya pembicaraan genre tersebut. Secara garis besar Lukens mengelompokkan genre sastra anak ke dalam enam macaam, yaitu realisme, fiksi formula, fantasi, sastra tradisional, puisi dan nonfiksi dengan masing-masing mempunyai jenis lagi. 1). Realisme. Dalam sastra dapat dipahami bahwa cerita yang dikisahkan itu mungkin saja ada dan terjadi walau tidak harus benar-benar ada dan terjadi. Peristiwa dan aksi serta jalinan peristiwa dan aksi yang dikisahkan masuk akal dan logis. Genre realisme sendiri terbagi atas cerita realisme, realisme binatang, realisme historis, realisme olahraga. 2). Fiksi formula. Sebagaimana sebutannya, fiksi formula seolaholah telah memiliki "formula", rumus, pola alur, pola karakter, dan lain-lain yang bersifat stereotip. Walau hal itu tidak mengurangi orisinalitas cerita yang dikreasikan oleh penulis. Jenis sastra anak yang dapat dikategorikan ke dalam fiksi formula adalah cerita misteri dan detektif, cerita romantic, dan novel serial. 3). Fantasi. Lukens (dalam Nurgiantoro, 2019:23) menyebut cerita fantasi sebagai cerita yang menawarkan sesuatu yang sulit diterima oleh akal. Cerita fantasi dikembangkan lewta imajinasi yang lazim dan dapat diterima sehingga sebagai sebuah cerita dapat diterima oleh pembaca. Yang tergolong dalam fantasi adalah cerita fantasi, fantasi tingkat tinggi, dan fiksi sains. 4). Sastra tradisional. Istilah tradisional dalam kesastraan (traditional literature atau folk literature) menunjukkan bahwa bentuk itu berasal dari cerita yang telah mentradisi, tidak diketahui mulainya dan siapa penciptanya, dan dikisahkan secara turn-temurun secara lisan. Yang termasuk dalam jenis ini adala, fable, dongeng rakyat, mitologi, legenda, dan epos. 5). Puisi. Genre puisi anak dapat berwujud puisipuisi lirik tembang-tembang anak tradisional, lirik tembang-tembang ninabobo, puisi naratif, dan puisi personal.6). Bacaan Nonfiksi. Bacaan nonfiksi sastra ditulis secara artistic sehingga jika dibaca oleh anak, anak akan memperoleh pemahaman sekaligus kesenangan. Ia akan membangkitkan pada diri anak perasaana keindahan yang berwujud efek emosional dan intelektual. Yang tegolong dalam jenis ini adalah buku informasi dan biografi.

Buku Kumpulan cerita Anak Cerdas ditulis oleh Durroh Fuadin diterbitkan tahun 2020 oleh Elex Media Komputindo. Buku ini berisi 10 cerita anak yang berjudul Misteri di Desa Ayers, Hop! Hop!, Hop! Byur!, Berlibur ke Rumah Nenek, Ke mana Matahari?, Misteri Ikan Bibi Dixiet, Penyihir Di Rumahku, Temui Aku Di Tempat Rahasia, Ke Mana Sanki?, Batu Besar Di Tengah Desa, Buah Manis Berwarna Merah.

\section{METODOLOGI PENELITIAN}

Pendekatan dalam penelitian ini adalah pendekatan kualitatif deskriptif. Pendekatan kualitatif menyajikan data-data dalam bentuk deskriptif yaitu berupa kata-kata, gambar, bagan, dan bukan angka-angka. Ratna (2013: 46) menyebutkan metode kualitatif pada dasarnya sama dengan metode hermeneutik. Artinya baik metode hermeneutik, kualitatif, analisis isi, secara keseluruhan memanfaatkan cara-cara penafsiran dengan penyajian data bentuk deskripsi.

Deskriptif pada penelitian ini tidak memerlukan wawancara, kuisioner, dan angket. Sebagaimana dijelaskan oleh Moleong (2016: 05) penelitian kualitatif merupakan suatu penelitian yang bermaksud untuk memahami tentang suatu peristiwa serta gejala yang dialami oleh subyek penelitian yang secara menyeluruh dan dengan menggunakan gambaran kata-kata serta bahasa yang berada dalam konteks alamiah dengan memanfaatkan berbagai metode alamiah. Selanjutnya Moleong (2016: 07) juga menegaskan bahwa penelitian kualitatif adalah penelitian yang menggunakan pendekatan naturalistik untuk mencari dan menemukan pengertian atau pemahaman tentang fenomena dalam suatu latar yang berkonteks khusus. 
Pengertian ini hanya mempersoalkan dua aspek yaitu pendekatan penelitian yang digunakan adalah naturalistik sedang upaya dan tujuannya adalah memahami suatu feomena dalam suatu konteks khusus.

Penelitian kualitatif selalu bersifat deskriptif artinya data yang dianalisis dan hasilnya berbentuk deskripstif fenomena, tidak berupa angka-angka tentang hubungan variabel. Semua yang disajikan menjadi kunci dari sebuah penelitian. Dalam hal ini laporan penelitian berisi kutipan-kutipan dari sumber data sebagai ilustrasi untuk memberikan paparan dan penguatan atas masalah fenomenologi dan pesan religius dari tindakan, sikap, dan pemikiran tokoh dalam novel pada objek yang diteliti.

\section{PEMBAHASAN}

Cerita anak mengandung banyak nilai yang dapat dijadikan pelajaran dalam kehidupan sehari- hari. Hal ini sangat berguna bagi anak- anak yang akan menjalani kehidupan di masyarakat, hal ini seperti tampak dalam buku Kumpulan Cerita Anak Cerdas.

Cerita pertama berjudul Misteri Di Desa Ayers cerita ini mengandung nilai semangat atau pantang menyerah hal ini tampak dalam kutipan, "Aha!" ujar si detektif karena ia menemukan sebuah jejak kecil di antara tumpukan jerami. Detektif itu mencoba mencari jejak yang lain. Dia yakin jejak itu akan memberinya petunjuk. Benar saja, ternyata ada jejak yang sama juga terdapat di pagar yang bengkok.

Dalam data tersebut mengandung nilai semangat atau pantang menyerah, hal itu tampak dalam kutipan yang menceritakan seorang detektif yang berusaha menemukan pelaku dari lenyapnya hewan para penduduk di suatu desa. Setelah berusaha sekuat tenaga, akhirnya dia berhasil menemukan tersangkanya yaitu seekor buaya.

Cerita kedua berjudul Hop! Hop! Hop! Byur! Yang mengandung nilai menjaga kebersihan, hal itu tampak dalam kutipan,

"Awas! ada sabun!" teriak saudaraku yang berwarna kuning.

Tubuh si kuning dan teman-teman di dekatnmya meleleh. Mereka tampak layu. Oh, tidak! Ini mengerikan!

Sabun itu menyapu semua saudaraku... termasuk tubuhku. Aduuuh, tubuhku terasa sakiit...
Berdasarkan kutipan tersebut diceritakan bahwa kuman akan mati bila kita rajin mencuci tangan menggunakan sabun.hal ini mengajarkan kepada anak tentang nilai menjaga kebersihan.

Cerita ketiga berjudul Kemana Matahari?. Cerita ini mengisahkan tentang perputaran mahari dalam mengelilingi bumi. Hal ini tampak dalam kutipan,

"Lho ke mana matahari." Bunga-bunga tidak mendengar ucapan awan. Kini mereka tidak bias melihat Matahari karena tertutup awan.

Makin lama sinar matahari makin meredup. Langit menjadi gelap. Rupanyasemakin banyak awan yang dating. Tak lama kemudian turun hujan.

Pada kutipan cerita tersebut mengandung nilai menjaga lingkungan sekitar. Hal ini mengajarkan kepada anak-anak untuk menjaga kelestarian lingkungan di sekitar mereka.

Cerita berikutnya berjudul Penyihir di Rumahkau, cerita ini mengisahkan tentang orang tua yang sangat sayang pada anaknya, sehingga menurut anaknya orang tuanya dapat mewujudkan segala keinginannya seperti seorang penyihir. Hal ini tampak dalam kutipan,

"Setiap pagi, penyihir itu mengubah kain-kain yang tadinya basah, menjadi kering dan halus lembut.

Penyihir itu juga bias mengubah daundaun yang pahit menjadi lezat! Tepungtepung yang hambar bias dia ubah menjadi kue empuk yang meтbuat sетиа orang berselera."

Pada data tersebut terkandung nilai atau pembelajaran untuk selalu menghormati dan menyayangi orang tua yang selalu dapat mewujudkan apa yang kita inginkan.

Pada cerita berikut yang berjudul Batu Besar di Tengah Desa mengisahkan tentang bencana angin kencang yang melanda sebuah desa sehingga seluruh penduduk desa tidak berani keluar rumah. Keesokan harinya ternyata ada sebuah batu besar yang terbawa angin kencang tadi sehingga menutup jalan desa. Hal itu tampak dalam kutipan,

“Aha!” pak kepala desa segera berseru.

Dia memerintahkan beberapa warga untuk pulang mengambil alat pemecah batu. Maka, semua warga pun pulang. Mereka mengambil alat apa saja yang berguna untuk memecah batu besar itu. 
Warga pun bahu membahu menghancurkan batu itu menjadi bagianbagian yang lebih kecil.

Setelah ukuran batu itu menjadi lebih kecil, dengan mudah warga dapat bergotong royong memindahkan ke tepi jalan.

Jalan pun bersih kembali. Batu besar tadi sudah hilang. Orang-orang pun bisa melintas lebih lancar.

Berdasarkan kutipan tersebut terkandung nilai gotong royong. Hal ini mengajarkan kepada anak-anak bahwa dalam menyelesaikan masalah akan lebih mudah jika diselesaikan secara bersama atau bergotong royong.

\section{PENUTUP}

Berdasarkan hasil pembahasan dalam artikel ini dapat dismpulkan bahwa kegiatan membaca buku ceritaatau mendongeng memiliki banyak manfaat, karena dalam cerita anak cerdas mengandung nilai- nilai diantaranya nilai semangat, menjaga kebersihan, menjaga kelestarian lingkungan, menyayangi orang tua, dan gotong royong. Nilai-nilai tersebut sangat bermanfaat untuk membentuk karakter anak dan juga dapat dijadikan bahan pelajaran bagi anakanak dalam kehidupan sehari- hari.

\section{REFERENSI}

Teeuw. 2013. Sastra dan Ilmu Sastra. Bandung: PT. Dunia Pustaka.

Fuadin K, Durroh. 2020. Kumpulan Cerita Anak Cerdas.Jakarta:PT Elex Media Komputindo.

Listiyaning, Eka dan Purbarani Jatining Panglipur.2017. Sastra Anak Sebagai Sarana Pembelajaran Bahasa dan Sastra untuk Menumbuhkan Berbagai Karakter di Era Global. https://jurnal.unej.ac.id.

Nurgiantoro, Burhan. 2019. Sastra Anak Pengantar Pemahaman Dunia Anak.Yogyakarta: Gajdah Mada University Press.

Sarumpaet-Riris K. Toha. 2017. Pedoman Penelitian Sastra Anak. Jakarta: Yayasan Pustaka Obor Indonesia. 